\title{
A comparison of the Paleo- Mesoproterozoic LIPs and black shales in the North China and Northern Australian cratons
}

SHUAN-HONG ZHANG ${ }^{1 *}$, RICHARD E. ERNST ${ }^{2,3}$, JUNLING PeI $^{1}$, GuOHUI HU ${ }^{1}$, JiAN-Min LiU ${ }^{1}$

${ }^{1}$ Institute of Geomechanics, Chinese Academy of Geological Sciences, MNR Key Laboratory of Paleomagnetism and Tectonic Reconstruction, China ("correspondence: tozhangshuanhong@163.com)

${ }^{2}$ Department of Earth Sciences, Carleton University, Canada

${ }^{3}$ Faculty of Geology and Geography, Tomsk State University, Russia

Large igneous provinces (LIPs) can provide robust tools for Precambrian paleographic reconstructions [1]. Previous results show that Phanerozoic LIPs have a significant influence on global climate changes and mass extinction events, and established a temporal correlation of LIPs with oceanic anoxic events and mass extinctions [2]. Comparisons of LIPs and black shales in different cratons can provide important constraints on paleographic reconstructions and a better understanding of the environmental effect of LIPs.

The ca. 1.32 Ga Yanliao LIP recently identified from the northern North China Craton (NCC) is composed mainly of dolerite sills and minor dolerite sills [3]. It is comparable with the Derim Derim-Galiwinku LIP in the Northern Australian Craton (NAC) that is composed of Derim Derim dolerite sill (baddeleyite U-Pb of $1324 \pm 4 \mathrm{Ma}$ ) and Galiwinku dolerite dyke swarm (baddeleyite U-Pb of $1325 \pm 36 \mathrm{Ma}$ ). The Yanliao and Derim Derim-Galiwinku LIPs are interpreted to represent separated fragments of the same LIP by continental breakup [3].

A comparison of black shales provide further evidence for connections (or at least near neighbors) between the NCC and NAC during the Paleo-Mesoproterozoic period. Recent zircon U-Pb ages of tuffs provide new constraints on the deposition ages of black shales in the NCC. The Chuanlianggou Formation in the northern NCC and the Cuizhuang Formation in the southern NCC were deposited around $1.64 \mathrm{Ga}$ and is similar to the deposition ages of the balck shales within the Barney Creek Formation in the NAC. The ca. $1.38 \mathrm{Ga}$ deposition age of the Xiamaling Formation in the NCC is similar to that of the Velkerri Formation in the McArthur Basin in the NAC.

[1] Ernst et al. (2016) Nature Geosci 9, 464-469. [2] Percival et al. (2015) Earth Planet Sci Lett 428, 267-280. [3] Zhang S.-H. et al. (2017) Earth Planet Sci Lett 465, 112-125. 